\title{
Immunological Study on Salmonellae Isolated from Different Sources
}

\author{
Enas A.shedeed ${ }^{1}$, Mahmoud D. El-Hariri ${ }^{2}$, Soad A.Nasef ${ }^{1}$ and J. El Jakee ${ }^{2 *}$ \\ ${ }^{I}$ Reference Laboratory for Veterinary Quality Control on Poultry Production-Animal Health Research Institute, Dokki, Cairo. \\ ${ }^{2}$ Faculty of Veterinary Medicine, Cairo University, Giza, Egypt. \\ *Corresponding author’s Email: jeljakee@ yahoo.com; ORCID: 0000-0002-5299-3783
}

Received: 19 Feb. 2020

Accepted: 25 Mar. 2020

\begin{abstract}
Salmonella infection is a critical veterinary and medical problem worldwide and is a major issue in the food industry. Non-typhoidal Salmonella is known as an important pathogen causing gastroenteritis. The Outer Membrane Proteins (OMPs) of Gram negative bacteria are significant for virulence, host immune responses and drug therapy targets. Enhanced diagnosis of live poultry colonized with Salmonella species is required to avoid foodborne diseases. The present study was based on molecular characterization of OMPs among four Salmonella serovars (S. Typhimurium, $S$. Enteritidis, $S$. Kentucky and $S$. Anatum) using sodium dodecyl sulfate-polyacrylamide gel electrophoresis. The OMPs profiling showed more than 70 protein bands ranged in size from $208 \mathrm{kDa}$ to below $16 \mathrm{kDa}$ which were detected using Total Lab 1D 12.2 software. All Salmonella strains had a band at 54-60 kDa, 45-53 kDa, 36-39 kDa and 26-31 kDa. Eleven strains exhibited a band at 41-46 kDa and 33-35 kDa. Nine strains had a band at 61-69 kDa. Eight strains exhibited a band at 135-145 kDa and 72-79 kDa. Seven strains had a band at 108-123 kDa and 83-91 $\mathrm{kDa}$. In the Western blot analysis, the prepared hyperimmune anti serum of each Salmonella serovars reacted with the $35 \mathrm{kDa}$ protein band. It is concluded that the identification of novel immunogenic proteins would be useful in developing ELISA-based diagnostic assays with a higher specificity.
\end{abstract}

Key words: Outer Membrane Proteins, Salmonella, SDS-PAGE, Western blotting.

\section{INTRODUCTION}

Salmonellosis is the most commonly reported foodborne zoonotic disease in humans that can cause chronic illness, mortality and societal expenses. The causative agent of salmonellosis includes a variety of Salmonella enterica serovars. While more than 2500 serovars of S. enterica have been reported, among those $S$. Typhimurium was reported to be second most prevalent serovar of zoonotic significance isolated from humans worldwide. Several countries are confronting this public health crisis due to its resistance to antimicrobial agents and rapid transmission of Salmonella via food and water. These organisms are associated with poultry gut, thus the consumption of contaminated poultry meat, egg and contact with infected birds are the main routes of transmission to humans (Prejit et al., 2018). Salmonella is categorized according to the different antigens found in the cell wall of bacteria, the $\mathrm{O}$ antigen is recognised as somatic antigens and the $\mathrm{H}$ antigen is constituted by polymerized subunits of flagellin, while the virulence-associated antigen expressed in the surface of some Salmonella strains is known as Vi or K antigen. The use of a number of antisera directed to some of those surface antigens of Salmonella constitutes a universal subtyping method called serotyping (QuintanaOspina et al., 2018). The predominant serotypes present in Egyptian poultry farms are $S$. enterica serovar Typhimurium and $S$. enterica serovar Enteritidis (Sedeik et al., 2019).

Non-typhoidal Salmonella is a fundamental cause of food-borne disease globally. It is a universal public health interest, reporting more than 94 million cases and 115,000 deaths every year, with disproportionate influence in developing countries. Salmonellae were revealed in $5 \%$ of minced meat samples, $10 \%$ of the 20 burger samples, $35 \%$ of sausage samples and $25 \%$ of poultry products. Salmonella isolates were revealed as $S$. Infantis, $S$. Lagos, $S$. Bolombo, $S$. Cerro, $S$. Enteritidis, $S$. Kentucky, $S$. Newlands, $S$. Newport, $S$. Saintpaul, $S$. Sandiego, $S$. Senftenberg and $S$. Typhimurium (EI Jakee et al., 2014).

Another serious health problem that affects antimicrobial treatment is the existence of multidrugresistant (MDR). Many studies show that infections 
produced by MDR strains are more serious than these produced by susceptible strains (Djeghout et al., 2017). Food-borne salmonellosis is a massive public health problem not only in the developing countries but also in industrialized countries, resulting in increasing incidence of enteric diseases, hospitalizations and even deaths every year globally. As one of the most common food borne pathogens, Salmonella infects more than 160,000 individuals in the European Union annually, with a morbidity rate of 35 cases per 100,000.6 Salmonella was the second etiologic agent which is laboratory confirmed responsible for 229 (30\%) recorded outbreaks of food poisoning in the United States and the economic cost of Salmonella infections is $\$ 2.4$ billion annually (Wang et al., 2017). Several diagnostic tests for detecting of Salmonella infections in poultry were developed. $S$. Typhimurium (0.6) and $S$. Enteritidis (0.5\%). were isolated from eggs (El Jakee et al., 2016).

Cultural isolation is the standard technique for detecting salmonellae in hatcheries and breeding flocks. Cultural procedures for the detection of Salmonella, however, are laborious, costly, time-consuming and individual birds intermittently excrete $S$. enterica or may remove the infection completely. Therefore, the designing of dependable screening tests would help identify Salmonella presence in hatchery environments and flocks. Serological approaches such as ELISA could help to identify the existence of infected and carrier birds and also silent transmission throughout the flock, that can be missed by traditional bacteriological methods because of the sporadic Salmonella shedding (Manoj et al., 2015).

Improvement of detection methods and development of new vaccines would simplify the detection, characterization, and validation of previously unbeknown immunogenic proteins (Meyer et al., 2012). The outer membrane is a continued structure on Gram-negative bacteria surface and has special importance as among the potential protective immunity targets. Recent researches have tended to focus on the Outer Membrane Proteins (OMPs) proposing the presence of Salmonella protective immunogenic elements. The OMPs have been identified to be immunogens for evolving active/protective immunity against Salmonella and thus, have tremendous possibility to be used in vaccination. OMPs have been inspected as potential candidates for vaccine, virulence factors and those surface exposed proteins play a vital role in pathogenic mechanisms including host cells motility, adhesion and colonization, injection of toxins and cellular proteases, and the formulation of channels for the sweeping of antibiotics (Singh et al., 2017).

The OMPs are effective immunogens on the bacterial surface, which have been used in many trials to check their ability as a vaccine candidate in poultry. Studies have been focused on evolution of OMPs diagnostic antigen. OmpC, OmpF, OmpD are the principal Salmonella OMPs (Prejit et al., 2018).

The present study aimed to characterize the OMPs of Salmonella serovars ( $S$. Typhimurium, $S$. Enteritidis, $S$. Kentucky and $S$. Anatum) collected from different sources and to identify antigenic proteins by Western blotting.

\section{MATERIALS AND METHODS}

\section{Ethical approval}

The study was approved by the Institutional Animal Care and Use Committee of Cairo University, Giza, Egypt (Vet CU20022020145).

\section{Bacterial strains}

Twelve Salmonella isolates collected from duckling, chicken, and poultry feed were obtained from the reference laboratory for veterinary quality and control on poultry production (Table 1).

Table1. Salmonella strains used in the present study

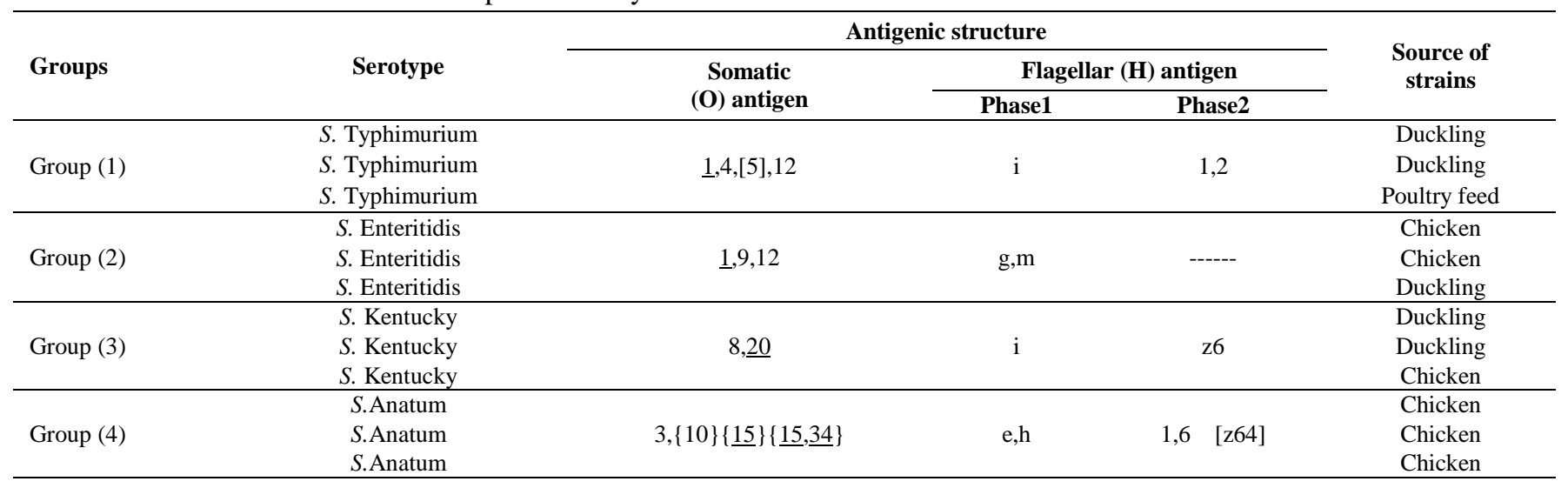




\section{Confirmation of the isolates}

The collected isolates were tested for purity using xylose lysine deoxycholate (Oxoid). Confirmation of the isolates using biochemical characterization and serological identifications (with agglutination tests with specific $\mathrm{O}$ and $\mathrm{H}$ antisera, and classified according to the KauffmannWhite-Le Minora scheme) were performed (Quinn et al., 2002).

\section{Real-time PCR}

Molecular confirmation of Salmonella isolates was done with Salmonella specific primers targeting the invA gene by real-time PCR. DNA Extraction performed according to the QIAamp DNA mini kit. Specific primers were used and the cycling program was done according to Daum et al. (2002). Master Mix was prepared according to the Quantitect probe Real-time PCR kit. Results were monitored by the Stratagene MX3005P set.

\section{Isolation of outer membrane proteins}

The OMPs from Salmonella were isolated as described by Verdugo-Rodriguez et al. (1993) with some modifications. Twenty Four hours cultures of bacterial cells in nutrient broth were centrifuged at $1,400 \mathrm{xg}$ at $4^{\circ} \mathrm{C}$ for 10 minutes. The bacterial cell pellet thereafter, resuspended in phosphate-buffered saline (PBS, pH 7.4), and sonicated at a setting of $20 \mathrm{kHz}$ or 20,000 cycles/sec (Vi bra Cell sonicator, Sonic \& Material Co., Danbury, Connecticut, USA). Sonicated cells were centrifuged at $1,400 \mathrm{x} \mathrm{g}$ at $4^{\circ} \mathrm{C}$ for 10 minutes, and centrifuge the gained supernatant at $100,000 \mathrm{xg}$ at $4^{\circ} \mathrm{C}$ for 30 minutes and the pellet resuspended in $20 \mathrm{ml}$ of $\mathrm{PBS}, \mathrm{pH} 7.4$ containing $20 \%$ Triton $\mathrm{X}-100$ and incubated at $37^{\circ} \mathrm{C}$ for 20 minutes. The centrifugation step was repeated and the pellet was resuspended in $1 \mathrm{ml}$ of PBS, $\mathrm{pH} 7.4$, and stored at $-20^{\circ} \mathrm{C}$ until use. The protein content was analyzed by the NanoDrop®ND-1000 Spectrophotometer (NanoDrop Technologies, Wilmington, DE USA) at $280 \mathrm{~nm}$ at reference laboratory for veterinary quality and control on poultry production. It was suitable for performing Electrophoresis.

Salmonella species OMP separation by sodium dodecyl sulfate-polyacrylamide gel electrophoresis

Analysis of protein profiles of the Salmonella serovars ( $S$. Typhimurium, $S$. Enteritidis, $S$. Kentucky, and $S$. Anatum) was done by sodium dodecyl sulphate polyacrylamide gel electrophoresis which was performed on $12 \%$ separating and 5\% stacking gels using a discontinuous buffer system in a biorad Protein II vertical unit (BioRad, Richmond, CA, USA) as defined by
Laemmli (1970). The OMP extracts were solubilized in treatment buffer containing $\beta$-Mercaptoethanol. Samples boiled in a water bath for 90 seconds then quickly transferred to ice water. The separation was carried out at a constant current $150 \mathrm{~V}$ per gel for about $4 \mathrm{hrs}$. Gels were stained with Coomassie Brilliant blue R-250 staining solution for $4 \mathrm{hrs}$ at room temperature. After staining, the slab gel was immersed in destaining solution repeatedly until the background became clear (about 3 hours). Finally, gel was washed with distilled water. The gel was viewed and photographed under gel documentation. The pictures of gel and marker were loaded on computer program (TollLab) to calculate the molecular weights of peptide bands.

\section{Preparation of hyperimmune sera against Salmonella serovars}

Hyperimmune antiserum was obtained from 20 chicks (5 chicks for each strain) inoculated IP with $10^{11}$ formalin killed Salmonella serovars ( $S$. Typhimurium, $S$. Enteritidis, $S$. Kentucky and $S$. Anatum) solubilized in Auspharm adjuvant as emulsion $(0.5 \mathrm{mg} /$ dose $)$ at 19 and 33 days of age, and an oral booster at 47 days of age. Blood was collected after 7 days and serum was prepared and stored at $-20^{\circ} \mathrm{C}$ according to the protocol of MuirWendy et al. (1998).

\section{Western blot}

Proteins from culture supernatant gels were blotted on nitrocellulose membranes in $25 \mathrm{mM}$ Tris- $\mathrm{HC} 1,192$ $\mathrm{mM}$ glycine buffer, $\mathrm{pH} 8.3$, containing methanol $20 \% \mathrm{v} / \mathrm{v}$ (Neal, 1981). The transfer was influenced by a current of $100 \mathrm{~mA}$ overnight in a Bio-Rad Trans blot cell. Free protein sites were saturated by incubation in blocking buffer containing newborn calf serum (Gibco) $10 \% \mathrm{v} / \mathrm{v}$ in phosphate-buffered saline, $\mathrm{pH} 7-4$, Triton X-100 0.2\% $\mathrm{v} / \mathrm{v}$ for $30 \mathrm{~min}$. The nitrocellulose membrane was then incubated in anti-Salmonella diluted 1: 20000 PBS1 in 50 in blocking buffer for $1.5 \mathrm{~h}$. After washing three times for 15 minutes each in phosphate-buffered saline, $\mathrm{pH} 7.4$, Triton X-100 0.2\% v/v the nitrocellulose membrane was incubated with Rabbit -anti chicken horse reddish peroxidase-conjugated Ab (KPL) 1:5000 (Secondary Ab) The paper was washed afterward and a chromogen substrate containing tetramethylbenzidine was added.

Calculation of molecular weights of the proteins

The relative migration values of the migrated protein fraction were calculated in relation to protein marker by Total Lab 1D 12.2 software. 


\section{RESULT AND DISCUSSION}

Salmonellae are significant gastrointestinal pathogens that pose a global threat to public health. A total of 12 Salmonella strains were included in the study, 5 of them were isolated from duckling, 6 from chicken and one from poultry feed. The isolates were confirmed to be salmonellae using conventional and molecular methods (Figure 1). The outer membrane is a persistent feature on Gram-negative bacteria surface and has particular significance as one of the potential targets for protective immunity. Determination of the protein content plays an important role in bacterial classification, identification, typing, and comparative studies. New searches on OMPs have suggested the presence of Salmonella protective immunogenic components (Singh et al., 2017).

The results of SDS-PAGE showed that more than 70 protein bands ranged in size from $208 \mathrm{kDa}$ to below 16 kDa. (Figure 2). All Salmonella strains had a band at 54$60 \mathrm{kDa}, 45-53 \mathrm{kDa}, 36-39 \mathrm{kDa}$, and 26-31 kDa. Eleven strains had a band at 41-46 kDa and 33-35 kDa. Nine strains had a band at 61-69 kDa. Eight strains had a band at 135-145 kDa and 72-79 kDa. Seven strains had a band at $108-123 \mathrm{kDa}$ and $83-91 \mathrm{kDa}$.

Protein bands of 78.1, 51.2, 41.5, 37.3, 35.1, 33.9, 30.7 , 27.6, 25.4, and $24 \mathrm{kDa}$ were detected in all Salmonella serovars and protein bands of 78.1, 51.2, and $41.5 \mathrm{kDa}$ appeared as major bands in all strains (Aksakal, 2010). The intense protein region which occupied the range from 14 and $45 \mathrm{kDa}$ constituted the Salmonella specific OMP bands, the higher molecular weight region (higher than $45 \mathrm{kDa}$ ) and at the lower molecular weight region (lower than $14 \mathrm{kDa}$ ) were bands related or associated to the OMP or residues of flagella and pilus protein (lower than $20 \mathrm{kDa}$ ) as recorded by Maripandi and Al-Salamah (2010).

All $S$. Typhimurium had a band at 96-84, 75-72, 69$63,47-45,43-42,37-36,34-33,27-26$ and 22-20 kDa. The majority of $S$. Typhimurium isolates $(74.3 \%)$ contained two OMPs of 30.6 and $34.6 \mathrm{kDa}, 6$ isolates $(17.1 \%)$ carried three OMPs of 27.2, 30.6 and $34.6 \mathrm{kDa}$ and three isolates $(8.6 \%)$ contained only a $30.6 \mathrm{kDa}$ (Maripandi and Al-Salamah, 2010). More than 21 OMP bands could be resolved from Salmonella Typhimurium, Salmonella Breanderp and Salmonella Lomita ranging in size from 61.0 kDa to 7.5 kDa (Osman and Marouf, 2014).

Among $S$. Enteritidis all strains had a band at 91-82, 72-67, 59-55, 45-43, 39-38, 37-35, 25-29, and $16 \mathrm{kDa}$. When the protein profiles of $S$. Enteritidis originating from chickens and turkeys were compared, no differences were found among the isolates within this serovar (Aksakal, 2010). S. Enteritidis with different OMPs bands were exhibited with a molecular weight ranged from 5-90 kDa and the major OMPs profiles of all $S$. Enteritidis isolates were homogenous with different expression in intensity of protein was observed by Maripandi and Al-Salamah (2010). The whole cell proteins of $S$. Typhimurium and $S$. Enteritidis showed similarity in analysis by SDS PAGE analysis, both strains yielded major bands at 71.4, 67.7, 44.0, and 30.3 kDa (Aksakal, 2010).

In the present study, all $S$. Anatum strains had a band 62-56, 54-52, 46-42, 41-40, 38-37, 35-33, 29-26, and 18$16 \mathrm{kDa}$. And all $S$. Kentucky strains had a band at 62-60, 54-51, 44-42, 38-37and 29-28 kDa. Salmonella Kentucky is among the most frequently isolated $S$. enterica serovars from food animals in the United States (Haley et al., 2019).

Infection with Salmonella is a significant medical and veterinary problem globally causing major concern in the food industry. This study implemented the Western blot technique to detect the presence of antigenic proteins of Salmonella strains. The result showed that hyperimmune antiserum of each Salmonella serovar reacted with the OMP $35 \mathrm{kDa}$ protein band (Figure 3). Another study carried out Western blot analysis against OMP of $S$. Enteritidis, serum antibodies from chicken infected with $S$. Enteritidis reacted with protein band at molecular weight 14.4 and $24 \mathrm{kDa}$, while antibodies raised against $S$. Typhimurium reacted with protein bands at molecular weights of 17, 24 and $31 \mathrm{kDa}$ (Maripandi and Al-Salamah, 2010). They recorded that 14.4 and $24 \mathrm{kDa}$ proteins were immune response protein and can use for vaccine development.

The finding of the present study highlighted that 35 kDa OMP of Salmonella serovars ( $S$. Typhimurium, $S$. Enteritidis, $S$. Kentucky and $S$. Anatum) is an immuneresponse protein. This protein can be used for vaccine preparation in future.

Jaradat and Zawistowski (1998) demonstrated the 35 $\mathrm{kDa}$ OMP contained an antigen common for all tested Salmonella species except atypical species such as $S$. Arizona. The results of the protection studies conducted by El-Tayeb et al. (2019) indicated that the highest protection was observed using the $38 \mathrm{kDa}$ OMP, which provided $100 \%$ protection to mice challenged with $50 \times$ LD50 of Salmonella Typhimurium SA3 and $75 \%$ protection to mice subjected to an even higher bacterial challenge of $100 \times$ LD50. Therefore, $38 \mathrm{kDa}$ OMP is a promising candidate for the vaccine development against $S$. Typhimurium.

Pandey et al. (2018) concluded that OMP 28 may be proven to be an effective candidate for the development of 
recombinant DNA vaccines against salmonellosis. Antigenic bands of Salmonella spp. of 10, 15, 17 and 40 $\mathrm{kDa}$ and $10,17,25,37$ and $75 \mathrm{kDa}$ were detected in 15 out of $18(83.3 \%)$ and 4 out of $18(22.2 \%)$ samples from chicken carcasses and egg surface, respectively. QuintanaOspina et al. (2018) suggested that rOmpC evident by a single protein band of $43 \mathrm{kDa}$ based indirect ELISA as a suitable screening tool for serological monitoring of poultry flocks. Recently, Li et al. (2019) established indirect ELISA using the IpaJ protein (a new antigen reported to be specific to $S$. Pullorum, and not detected in $S$. Gallinarum and $S$. Enteritidis) is a novel method for specific detection of $S$. Pullorum infection, and contribute to eradication of Pullorum disease in the poultry industry.

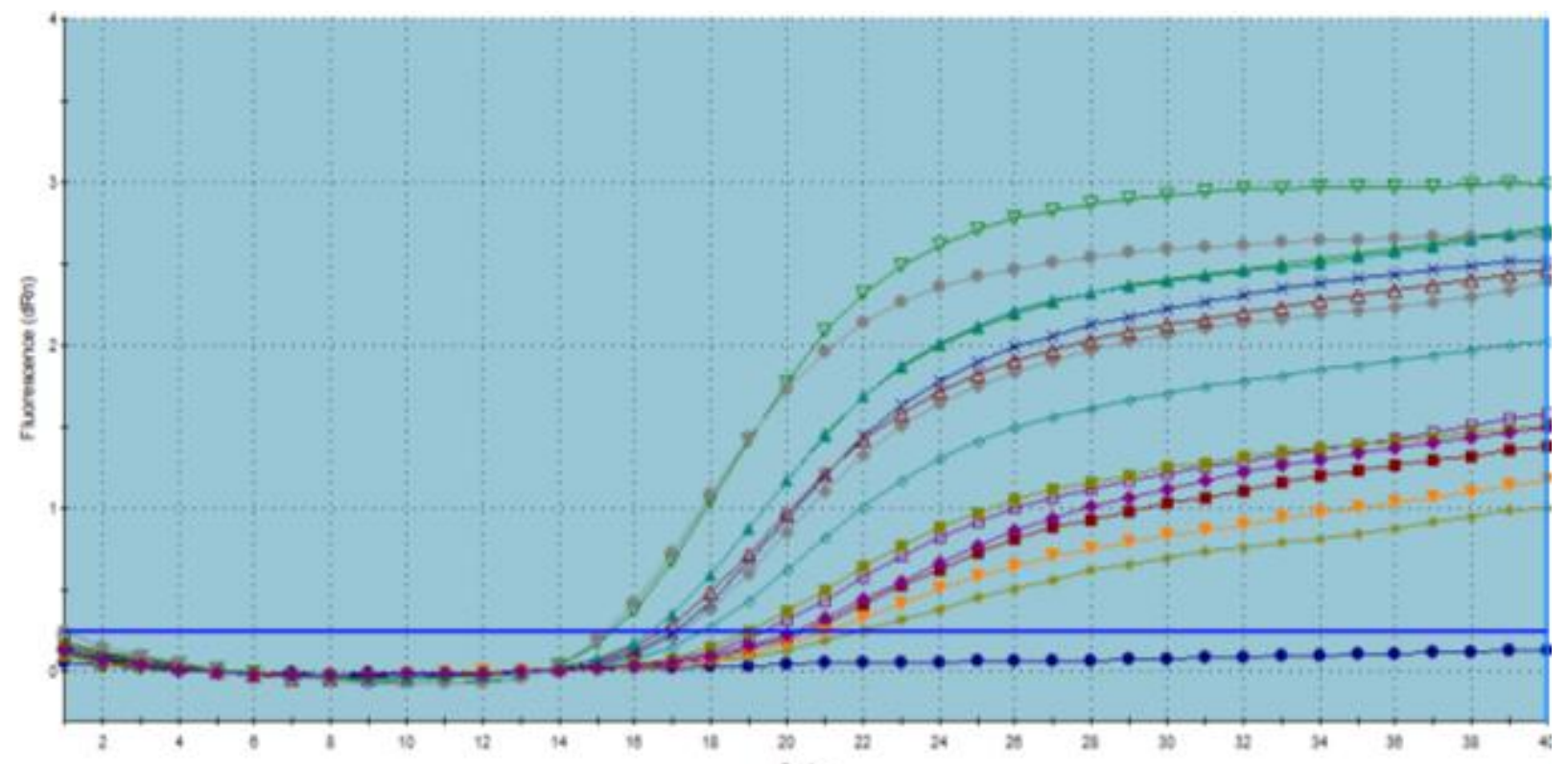

Figure 1.Amplification curves of real time PCR for detection of invA gene of studied Salmonella serovars by Stratagene MX3005P.
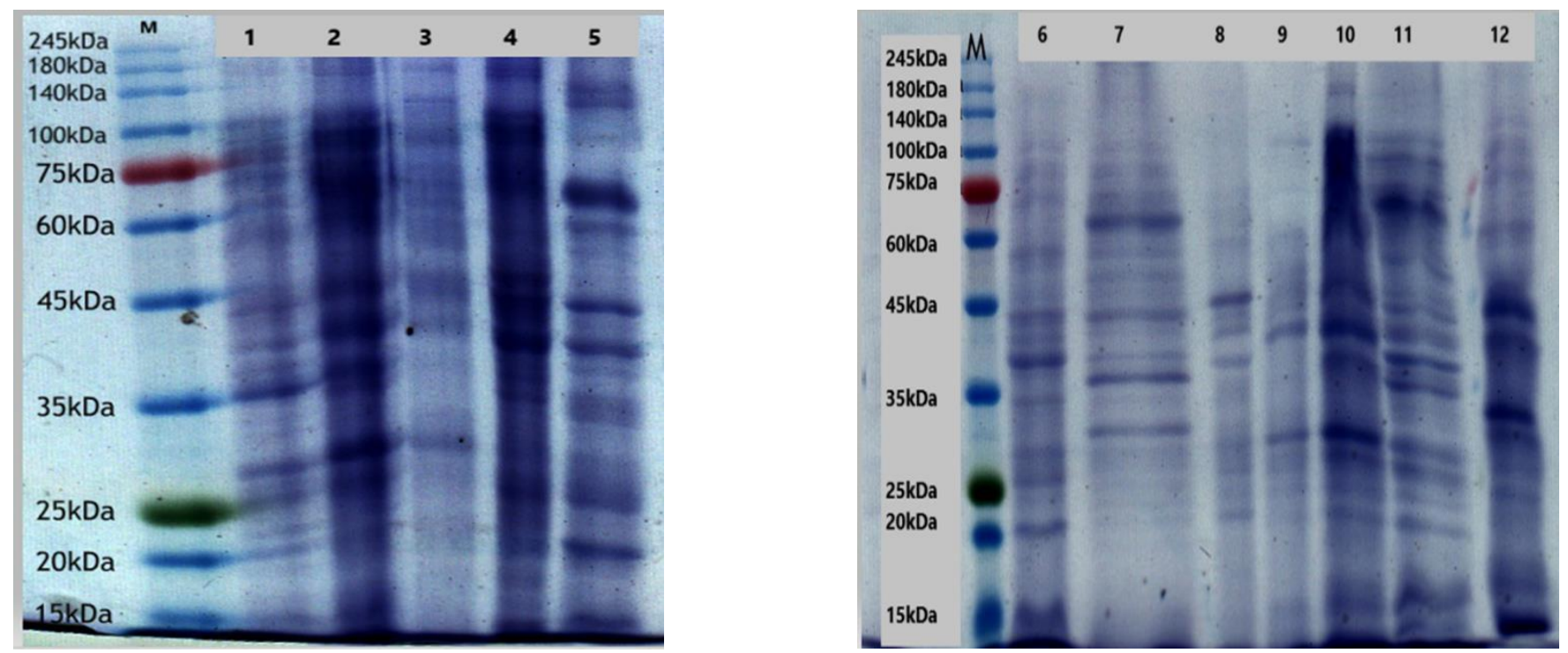

Figure 2. Sodium dodecyl sulphate poly acrylamide gel electrophoresis of outer membrane proteins extracted from different Salmonella strains and stained with Coomassie Brilliant Blue R-250. A): Lanes 1, 2 and 3: S. Typhimurium, Lanes 4 and 5: S. Enteritidis and Lane M: Molecular weight standards. B) Lane 6: S. Enteritidis, Lanes 7, 8 and 9: S. Kentucky, Lanes 10, 11 and 12: $S$. Anatum and Lane M; Molecular weight standards. 


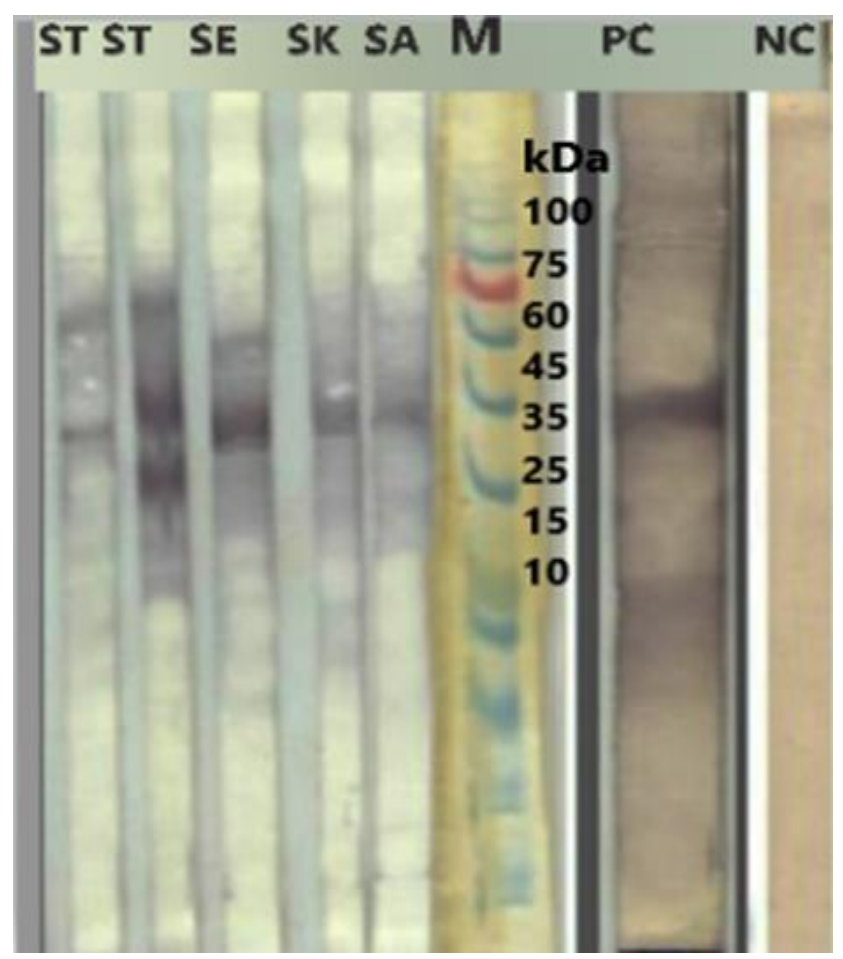

Figure 3. Immunoblot of sodium dodecyl sulfatepolyacrylamide gel electrophoresis of outer membrane proteins extracted from different Salmonella strains. Lane ST: $S$. Typhimurium, Lane SE: $S$. Enteritidis, Lane SK: $S$. Kentuky, Lane SA: $S$. Anatum, Lane M: Molecular weight standards (Marker proteins ranging from $100 \mathrm{kDa}$ to10 $\mathrm{kDa}$, Lane PC: positive control and Lane NC: negative control.

\section{CONCLUSION}

It is concluded that Salmonella OMP can play an essential role in the induction of immune response in the animals and can be employed as an effective candidate vaccine. Moreover, immunoblotting are helpful for the discovery of antigenic proteins that participate in cross-reactive responses across the different serovars. Further studies are needed to substantiate whether these antigenic proteins are likely to protect against Salmonella infection in vivo.

\section{DECLARATIONS}

\section{Acknowledgments}

This work was supported by Dr. Jakeen Eljakee, Dr. Mahmoud El-Hariri and Dr. Soad abdel-Aziz .We would like to express special thanks for them for their help, support and continuous advice.

\section{Competing interests}

No competing interest exists.

\section{Author's Contributions}

All authors contributed equally to this work

\section{REFERENCES}

Aksakal A (2010). Analysis of whole cell protein profiles of Salmonella serovars isolated from chicken, turkey and sheep faeces by SDSPAGE. Veterinarni Medicina, 55(6): 259-263. DOI: http://doi.org/ 10.17221/2986-VETMED

Daum LT, Barnes WJ, McAvin JC, Neidert MS, Cooper LA, Huff WB, Gaul L, Riggins WS, Morris S, Salmen A and Lohman KL (2002). Real-Time PCR Detection of Salmonella in suspect foods from a gastroenteritis outbreak in Kerr County, Texas. Journal of Clinical Microbiology, 40(8): 3050:3052. PMID:12149377; PMCID: PMC120641; $\quad$ DOI: $\quad$ http://doi.org/10.1128/JCM.40.8.30503052.2002

Djeghout B, Ayachi A, Paglietti B, Langridge GC and Rubino S (2017). An Algerian perspective on non-typhoidal Salmonella infection. Journal of Infection in Developing Countries, 11(8):583-590. DOI: https://doi.org/10.3855/jidc.9456.

El-Jakee J, Ata NS, El-Moez SA, Kandiel, MM and Radwan NM (2014). Assessment of the prevalence of salmonellae in food. International Journal of Current Microbiology and Applied Sciences, 3(3):30-42.

El Jakee J, Khelfa DEG, El-Safty MM, Seida AA, Marouf S, Hahne J, Mahmood Z and Nagy SS (2016). Multiplex PCR-based detection of Salmonella Typhimurium and Salmonella Enteritidis in specific pathogen free (SPF) and commercial eggs. Clinical Microbiology, 5(2): 241. DOI: https://doi.org/ 10.4172/2327-5073.1000241

El-Tayeb MA, Ibrahim ASS, Maany DA, Elbadawi YB and Al-Salamah AA (2019). Detection of virulence genes and investigation of the immunogenicity of outer membrane proteins of Salmonella enterica. Journal of Applied Biology \& Biotechnology, 7(05):6273. DOI: https://doi.org/ 10.7324/JABB.2019.70511

Haley BJ, Kim SW, Haendiges J, Keller E, Torpey D, Kim A, Crocker K, Myers RA and Van Kessel JAS (2019). Salmonella enterica serovar Kentucky recovered from human clinical cases in Maryland, USA (2011-2015). Zoonoses Public Health, 66:382-392 DOI:. https://doi.org/10.1111/zph.12571

Jaradat ZW and Zawistowski J (1998). Antigenically stable $35 \mathrm{kDa}$ outer membrane protein of Salmonella. Food and Agricultural Immunology, $\quad 10$ : 259-270. https://doi.org/10.1080/09540109809354989

Laemmli UK (1970). Cleavage of structural proteins during the assembly of the head of bacteriophage T. Nature, 227: 680-685. DOI: https://doi.org/10.1038/227680a0

Li Q, Zhu Y, Yin K, Xu L, Yin C, Li Y, Ren J, Yuan Y and Jiao X (2019). Purification of recombinant IpaJ to develop an indirect ELISA-based method for detecting Salmonella enterica serovars Pullorum infections in chickens. BMC Veterinary Research, 15:3. DOI: https://doi.org/10.1186/s12917-018-1753-0

Manoj J, Agarwal RK, Sailo B, Wani MA and Singh MK (2015). Evaluation of recombinant outer membrane protein $\mathrm{C}$ based indirect enzyme-linked immunoassay for the detection of Salmonella antibodies in poultry. Veterinary World, 8(8): 1006-1010.DOI: http://doi.org/10.14202/vetworld.2015.1006-1010

Maripandi A. and Al-Salamah AA (2010). Analysis of Salmonella Enteritidis outer membrane proteins and lipopolysaccharide profiles with the detection of immune dominant proteins. American Journal of Immunology, 6 (1): 1-6. DOI: http://doi.org/ 10.3844/ajisp.2010.1.6

Meyer T, Schirrmann T, Frenzel A, Miethe S, Stratmann-Selke J, Gerlach GF, Strutzberg-Minder K, Dübel S and Hust M (2012). Identification of immunogenic proteins and generation of antibodies 
against Salmonella Typhimurium using phage display. BMC Biotechnology, 12:29. DOI: http://doi.org/10.1186/1472-6750-1229

Muir Wendy I, Bryden WL and Husband AJ (1998). Evaluation of the efficacy of intraperitoneal immunization in reducing Salmonella Typhimurium infection in chickens. Poultry Science, 77:18741883. DOI: http://doi.org/10.1093/ps/77.12.1874

Neal BW (1981). Western Blotting: Electrophoretic transfer of proteins from sodium dodecyl sulfate-polyacrylamide gels to unmodified nitrocellulose and radiographic detection with antibody and radioiodinated protein A, Analytical Biochemistry, 112 (2):195203. DOI: https://doi.org/10.1016/0003-2697.

Osman KM and Marouf SH (2014). Comparative dendrogram analysis of OMPs of Salmonella enterica serotype Enteritidis with Typhimurium, Breanderp and Lomita isolated from pigeons. International Journal of Advanced Research, 2(1): 952-960. Available at: http:/www.journalijar.com/uploads/865_IJAR2553.pdf.

Pandey M, Saxena MK, Saxena A, Jha R, Rastogi SK and Kumar R (2018). Cloning, expression and purification of the outer membrane protein 28 of Salmonella enterica serovar Typhimurium for subunit vaccine development - a short communication. Veterinarski Arhiv, 88 (4): 559-568. DOI: https://doi.org/ 10.24099/vet.arhiv.170526

Prejit NS, Pratheesh PT, Mahesh SH and Vinod VK (2018). Cloning, sequencing and in silico characterization of OmpF protein of Salmonella Typhimurium for its immune-potential. International Journal of Current Microbiology and Applied Sciences, 7(5): 19912001. DOI: https://www.researchgate.net/publication/288938552
Quinn PJ, Markey BK, Carter ME, Donnelly WJ and Leonard FC (2002). Veterinary Microbiology and microbial diseases. Oxford, London: Black Well Scientific Publications.

Quintana-Ospina G, Holguin-Cespedes G, Rodriguez-Rodriguez V and Verjan-Garcia N (2018). Detection of Salmonella spp. antigens in Tolima poultry products by Western Blot. Veterinaria y Zootecnia, 12(1): 72-83. DOI: https://doi.org/10.17151/vetzo.2018.12.1.6

Sedeik ME, Nahed A, Awad AM, Elfeky SM, El-Hack MEA, Hussein EO, Alowaimer AN and Swelum AA (2019). Isolation, conventional and molecular characterization of Salmonella spp. from newly hatched broiler chicks. AMB Express, 96:136. DOI: https://doi.org/10.1186/s13568-019-0821-6

Singh Y, Saxena A, Kumar R, Bhatt P and Saxena MK (2017). Immunogenic outer membrane proteins (Omps) of Salmonella: Potential Candidate for sub-unit vaccine. Virology \& Immunology, 1(2):1-6.

Verdugo-Rodriguez A, Lay-Harn Gam, Oevl S, Koh CL, Puthucheary SO, Calva E and Pang T (1993). Detection of antibodies against Salmonella Typhi outer membrane protein (OMP) preparation in Typhoid fever patients. Asian Pacific Journal of Allergy and Immunology, 11: 45-52. DOI: https://doi.org/10.1016/S03357457(05)80159-5

Wang J, Li Y, Chen J, Hua D, Li Y, Deng H, Li Y, Liang Z and Huang J (2017). Rapid detection of food-borne Salmonella contamination using IMBs-qPCR method based on pagC gene. Brazilian Journal of Microbiology, 49: 320-328. DOI: https://doi.org/10.1016/j.bjm.2017.09.001 